\title{
Clinical and biological risk factors associated with inflammation in patients with type 2 diabetes mellitus
}

\author{
Mohammed S. Ellulu ${ }^{1}$ and Hanen Samouda ${ }^{2^{*}}$ (D)
}

\begin{abstract}
Background: Chronic inflammation has been associated with insulin resistance and related metabolic dysregulation, including type 2 diabetes mellitus (T2DM). Several non modifiable (i.e. genetic predisposition) and modifiable (i.e. sedentary lifestyle, energy-dense food) risk factors were suggested to explain the mechanisms involved in the development of inflammation, but are difficult to assess in clinical routine. The present study aimed to identify easy to asses clinical and biological risk factors associated with inflammation in patients with T2DM.

Methods: One hundred nine patients (51 men, 58 women), 28-60 years old, from seven primary healthcare centers in Gaza City, Palestine, took part to the cross-sectional study (November 2013-May 2014). Study participants had T2DM with no history of inflammatory diseases, cardiovascular diseases, medication and/or any health condition that might affect the inflammatory markers, interleukin 6 (IL-6) and C-reactive protein (CRP). Inflammation was defined for IL- $6 \geq 2 \mathrm{pg} / \mathrm{mL}$ and $C R P \geq 6 \mathrm{mg} / \mathrm{L}$. Multivariable logistic regressions were used to identify the relationship between inflammation and clinical and biological risk factors.
\end{abstract}

Results: After adjustment for age and gender, inflammation seems to increase with increased body mass index (BMI) (OR: 1.427 [1.055-1.931]), increased fasting blood glucose (OR: 1.029 [1.007-1.052]) and decreased adiponectin values (OR: 0.571 [0.361-0.903]).

There were also significant relationships between inflammation and BMI (OR: 1.432 [1.042-1.968]), fasting blood glucose (OR: 1.029 [1.006-1.052]) and adiponectin (OR: 0.569 [0.359-0.902]), after adjustment for smoking habits and physical activity.

Conclusion: Managing obesity and associated complications (i.e. hyperglycemia, high adiponectin levels) might help decreasing inflammation in individuals with T2DM.

Keywords: Diabetes, Inflammation, Adiponectin, Obesity, Body mass index, Cardiovascular diseases

\footnotetext{
* Correspondence: Hanene.Samouda@lih.lu

${ }^{2}$ Luxembourg Institute of Health, Population Health Department, L-1445

Strassen, Luxembourg

Full list of author information is available at the end of the article
}

(c) The Author(s). 2022 Open Access This article is licensed under a Creative Commons Attribution 4.0 International License, which permits use, sharing, adaptation, distribution and reproduction in any medium or format, as long as you give appropriate credit to the original author(s) and the source, provide a link to the Creative Commons licence, and indicate if changes were made. The images or other third party material in this article are included in the article's Creative Commons licence, unless indicated otherwise in a credit line to the material. If material is not included in the article's Creative Commons licence and your intended use is not permitted by statutory regulation or exceeds the permitted use, you will need to obtain permission directly from the copyright holder. To view a copy of this licence, visit http://creativecommons.org/licenses/by/4.0/ The Creative Commons Public Domain Dedication waiver (http://creativecommons.org/publicdomain/zero/1.0/) applies to the data made available in this article, unless otherwise stated in a credit line to the data. 


\section{Introduction}

Type-2 diabetes mellitus (T2DM) is a chronic disease characterized by insulin resistance and insulin deficiency, triggering hyperglycemia or raised glucose levels in the blood (fasting blood glucose $\geq 126 \mathrm{mg} / \mathrm{dL}$, postprandial glycaemia $\geq 200 \mathrm{mg} / \mathrm{dL}$ ) [1, 2].

T2DM has been emphasized as a leading cause of depression, retinopathy, blindness, non-traumatic lowerlimb amputation, neuropathy, renal failure, as well as a major cause of cardio- and cerebro-vascular diseases [3]. T2DM also affects the quality of life due to such as associated chronic complications [4]. Moreover, patients having T2DM are nearly twice as likely to die prematurely, compared to people free of type 2 diabetes. In particular, the number of deaths due to T2DM doubled worldwide, from 1990 to 2010 [5]. T2DM is also one of the 10 leading causes of death worldwide [6]. Unfortunately, about 463 million people live with diabetes worldwide, namely $9.3 \%$ of the global population in 2019, as reported in the 9th Edition of the Diabetes Atlas published by the International Diabetes Federation (IDF) [2]. 90\% of people living with diabetes worldwide have T2DM [6]. In addition, 374 million adults worldwide have prediabetes. The number of individuals living with diabetes worldwide is expected to reach 578 million by 2030 and about 700 million by 2045 [6]. Several risk factors have been suggested to explain the mechanisms involved in the development of T2DM. Modifiable risk factors include the disappearance of traditional food habits in favor of the consumption of energy-dense food including more animal and processed foods, animal fat, trans fatty acids as well as a higher consumption of sugar-sweetened beverages, refined grains and/or polished rice characterized by a high glycemic index. Furthermore, a drastic shift from an active agrarian lifestyle to a high sedentary lifestyle, due to motorization and urbanization, significantly decreased physical activity and increased energy surplus and T2DM development [7-11]. Amongst the non-modifiable risk factors, genetic predisposition counts for 40 to $70 \%$ in the T2DM development, depending on the preexistence of the disease in one or two parents, although a considerable part of this heritability is due to obesity [12]. Actually, T2DM development is greatly influenced by the gene-environment interactions. In particular, genetic factors determine the development of both obesity and T2DM by influencing taste, food preferences and dietary patterns, sedentary lifestyle, as well as basal metabolism and calories burn [13]. Additional risk factors of T2DM include age, smoking, stress, sleep disorders and depression [14-16]. Further clinical risk factors associated with T2DM development include abdominovisceral obesity, hyperglycemia, hypertension and dyslipidaemia, i.e. increased triglycerides and reduced highdensity lipoprotein cholesterol (HDL-cholesterol) [17]. However, inflammation has been shown to be the main trigger of T2DM. This is done under the stimulus of the aforementioned risk factors and through the chronic activation of pro-inflammatory cytokine pathways in the tissues targeted by the insulin-related action such as the adipose tissue, the muscle mass and the liver [18-21]. Even a minimal glucose abnormality has been shown to be related to inflammatory processes and T2D complications [22]. Inflammation has also been linked with other conditions associated with T2DM, such as atherosclerosis and blood coagulation, metabolic syndrome, heart failure, cardiometabolic diseases, renal diseases and cancers [23-28].

Inflammation is the main cause of developing type 2 diabetes mellitus, yet inflammatory markers are rather not specific (i.e. C-Reactive Protein or CRP) or not usually measured in clinic (i.e. interleukin 6 or IL-6). Also, common risk factors of inflammation and T2DM (i.e. genetic predisposition, sedentary lifestyle, energy-dense food intake) are difficult to assess in clinical routine. Thus, the present study investigated, in a sample of patients with T2DM, the clinical risk factors associated with inflammation that might be easily measured in clinical routine.

\section{Participants and methods}

Patients with type 2 diabetes mellitus (T2DM), defined by fasting glycaemia $\geq 126 \mathrm{mg} / \mathrm{dL}$ [2], and free from cardiovascular diseases, inflammatory diseases, medication and/or any health condition that might affect the inflammatory markers, interleukin 6 (IL-6) and C-reactive protein (CRP), were recruited from primary healthcare centers in Gaza City, Palestinian Territories. Seven centers were approached in Gaza City via cluster random sampling to obtain the data concerning the study. Medical history was investigated by the physicians. From the 484 screened patients, 109 individuals (51 men, 58 women), aged between 28 and 60 years, were eligible to participate in the study. All participants had a stable weight, or no fluctuation of more than $2 \%$ of their weight, for at least 2 months prior to the study. The enrollment of the participants in the study was performed between November 2013 and May 2014.

\section{Exclusion criteria include}

- Pre-existing cardiovascular diseases: Hypertension, atherosclerosis, coagulation, open heart surgery, coronary artery disease and/or any other major adverse cardiac event,

- Inflammatory diseases: Autoimmune diseases,

- Any health condition that might affect the inflammatory markers, interleukin 6 and CRP: Allergies, asthma, malignancies, as well as liver, renal, respiratory, thyroid and/or acute infectious diseases, 
- Using medication to treat cardiovascular and inflammatory conditions such as statin's cholesterollowering agent, nonsteroidal anti-inflammatory drugs (NSAIDs) and cyclooxygenase-2 (COX-2) inhibitors, and corticosteroids as anti-inflammtory drugs.

\section{Data collection}

The Case Report Form is reported in the Additional file 1.

\section{Clinical and biological data}

Age and gender were reported. Weight and height were measured. Body mass index (BMI) was calculated [BMI $\left(\mathrm{kg} / \mathrm{m}^{2}\right)=$ Weight $(\mathrm{kg}) /$ Height square $\left.\left(\mathrm{m}^{2}\right)\right]$ according to the World Health Organization (WHO) definition (2000) [29]. Seca 201 non-elastic tape was used to assess waist circumference (WC) at the level of the umbilicus and parallel to the floor, based on National Institute of Health (NIH) protocol (Lorenzo et al., 2007) [30]. Blood pressure (BP) was measured with the AccuSure ${ }^{\circ}$ Mercury Sphygmomanometer. Fasting blood glucose (FBG) was measured with a glucose oxidase enzymatic colorimetric method. Total cholesterol (TC) and triglycerides (TG) concentrations were assessed with commercial ELISA kits. C-Reactive Protein (CRP) concentrations were measured with a CRP turbidimetric latex 1:5 kit. Interleukin 6 (IL-6) and adiponectin concentrations were measured with Sigma-Aldrich ${ }^{\circ}$ ELISA kits via ELISA Reader.

\section{Clinical and biological risk factors}

Obesity was defined for BMI equal or more than $30 \mathrm{~kg} /$ $\mathrm{m}^{2}$ according to World Health Organization definition (2000) [29]. Abdominal obesity was defined for waist circumference equal or more than $102 \mathrm{~cm}$ for men and 88 $\mathrm{cm}$ for women according to National Institute of Health (NIH) protocol [30]. Hypertension was defined for systolic blood pressure (SBP) more than $140 \mathrm{mmHg}$ and/or diastolic blood pressure (DBP) more than $90 \mathrm{mmHg}$ according to the American Society of Hypertension and the International Society of Hypertension [31]. Hypercholesterolemia was defined for total cholesterol $\geq 200$ $\mathrm{mg} / \mathrm{dL}$ according to the National Cholesterol Education Program-Adult Treatment Panel III (NCEP-ATPIII) [32]. Hypertriglyceridemia was defined for triglyceride $\geq 150 \mathrm{mg} / \mathrm{dL}$ according to the NCEP-ATPIII [32]. Inflammation was defined for IL- $6 \geq 2 \mathrm{pg} / \mathrm{mL}$ and CRP $\geq 6 \mathrm{mg} /$ L, according to American Heart Association [33].

\section{Lifestyle habits}

The Global Physical Activity Questionnaire (GPAQ) Version-2 [34] was used to assess physical activity at work, to travel and on recreational activities. The Behavioral Risk Factor Surveillance System (BRFSS) modified form was used to assess smoking habits [35]. The study participants were asked whether they were smokers at the present time; whether they have ever smoked; how long have they been quit smoking; how much did they smoke before stop smoking; and whether they are currently exposed to smoke (Additional file 1).

\section{Ethical considerations}

All patients gave written informed consent before taking part to the study. All procedures were in accordance with the ethical standards and in line with the Helsinki Declaration of 1964, as revised in October 2008, in Seoul, Korea. Besides, the study was ethically approved by the Ethics Committee in Gaza (PHRC/HC/11/13) and the Ethical Committee of Universiti Putra Malaysia (JKEUPM), Ref Number FPSK_Mac (13) 04. Permission was obtained from the Director of Primary Healthcare Sector, Ministry of Health, Palestine.

\section{Statistical analysis}

Data were analyzed by using the Statistical Package for Social Sciences version 21.0 software (SPSS Inc., Chicago, IL, USA). Descriptive statistics, including frequencies and percentages, were used to describe the categorical variables analyses. The central tendency of continuous variables was expressed in mean \pm standard deviation (SD), minimal and maximal values. Univariate and multivariable logistic regressions were used to identify the clinical risk factors associated with inflammation. Odds Ratio (OR) were estimated. The multivariable models were adjusted on age, gender, smoking habits and/or physical activity. $P$ values $\leq 0.05$ were considered as statistically significant at the confidence level of $95 \%$.

\section{Results}

$46.8 \%$ of men $(N=51)$ and $53.2 \%$ of women $(N=58)$ with non-insulin dependent T2DM, 28-60 years old, participated in this study. $78.0 \%$ of the participants had obesity and $88.1 \%$ had abdominal obesity. $34.9 \%$ of the participants had hypertension, $61.5 \%$ had hypercholesterolemia, $57.8 \%$ had hypertriglyceridemia and $11.9 \%$ had inflammation (high levels of CRP or IL-6). 19.3\% of the participants were active smokers and $51.4 \%$ had low physical activity. The general characteristics of the population are presented in Table 1.

\section{Clinical and biological correlates}

Univariate analyses are detailed in Table 2. BMI (OR: 1.154 [1.039-1.282]), fasting blood glucose (OR: 1.011 [1.002-1.021]), triglycerides (OR: 1.005 [1.000-1.010]) and adiponectin (OR: 0.761 [0.615-0.942]) were associated with a higher risk to develop inflammation (Table 2).

Multivariable analyses showed that inflammation is most likely to be associated with the increase of BMI (OR: 1.427 [1.055-1.931]) and fasting blood glucose 
Table 1 General characteristics of the population $(N=109)$

\begin{tabular}{|c|c|c|c|}
\hline & N (\%) & Mean \pm SD & $(95 \% \mathrm{Cl})$ \\
\hline Age (years) & & $49.65 \pm 9.88$ & $48.30-51.72$ \\
\hline Men & $51(46.8 \%)$ & & \\
\hline Women & $58(53.2 \%)$ & & \\
\hline Obesity & 85 (78.0\%) & & \\
\hline Abdominal obesity & 96 (88.1\%) & & \\
\hline Hypertension & 38 (34.9\%) & & \\
\hline Hypercholesterolemia & $67(61.5 \%)$ & & \\
\hline Hypertriglyceridemia & $63(57.8 \%)$ & & \\
\hline Inflammation, hs-CRP $\geq 6$ mg/L & $42(38.5 \%)$ & & \\
\hline Inflammation, IL-6 $\geq 2 \mathrm{pg} / \mathrm{mL}$ & $23(21.1 \%)$ & & \\
\hline \multicolumn{4}{|l|}{ Anthropometry } \\
\hline BMI $\left(\mathrm{kg} / \mathrm{m}^{2}\right)$ & & $31.17 \pm 7.33$ & $30.74-33.04$ \\
\hline WC (cm) & & $108.65 \pm 15.24$ & $106.15-111.21$ \\
\hline $\mathrm{SBP}(\mathrm{mmHg})$ & & $127.06 \pm 17.27$ & 124.77-130.95 \\
\hline $\mathrm{DBP}(\mathrm{mmHg})$ & & $77.83 \pm 9.24$ & $77.15-80.57$ \\
\hline FBG (mg/dL) & & $184.28 \pm 59.79$ & 169.91-198.64 \\
\hline $\mathrm{TC}(\mathrm{mg} / \mathrm{dL})$ & & $185.03 \pm 30.97$ & 177.59-192.47 \\
\hline $\mathrm{TG}(\mathrm{mg} / \mathrm{dL})$ & & $193.52 \pm 106.3$ & 167.89-219.06 \\
\hline Adiponectin (mg/L) & & $9.71 \pm 0.43$ & $8.85-10.57$ \\
\hline hs-CRP (mg/L) & & $7.49 \pm 7.10$ & $5.17-8.71$ \\
\hline IL-6 (pg/mL) & & $1.78 \pm 0.63$ & $1.63-1.93$ \\
\hline \multicolumn{4}{|l|}{ Lifestyle habits } \\
\hline \multicolumn{4}{|l|}{ Smoking habits (N, \%) } \\
\hline Active smokers & $21(19.3 \%)$ & & \\
\hline Past smokers & $19(17.4 \%)$ & & \\
\hline Passive smokers & $22(20.2 \%)$ & & \\
\hline No smokers & $47(43.1 \%)$ & & \\
\hline \multicolumn{4}{|l|}{ Physical activity (N, \%) } \\
\hline High & $8(7.3 \%)$ & & \\
\hline Moderate & 45 (41.3\%) & & \\
\hline Low & 56 (51.4\%) & & \\
\hline
\end{tabular}

Abbreviations: $B M I$ body mass index, WC waist circumference, SBP systolic blood pressure, DBP diastolic blood pressure, FBG fasting blood glucose, $T C$ total cholesterol, TG triglyceride, $h s-C R P$ high sensitivity C reactive protein, IL-6 interleukin 6

values (OR: 1.029 [1.007-1.052]) and the decrease of adiponectin (OR: 0.571 [0.361-0.903]), after adjustment for age and gender.

After adjustment for age, gender, smoking and physical activity, high BMI (OR: 1.432 [1.042-1.968]) values, high fasting blood glucose concentrations (OR: 1.029 [1.006-1.052]), as well as low adiponectin (OR: 0.569 [0.359-0.902]) concentrations were associated with a higher risk of developing inflammation (Table 3).

\section{Discussion}

This study identified the clinical and biological risk factors associated with inflammation in a sample of patients with non-insulin dependent T2DM. Inflammation has been defined by the combination of CRP $\geq 6 \mathrm{mg} / \mathrm{L}$ and IL- $6 \geq 2 \mathrm{pg} / \mathrm{mL}$. The percentage of patients who had inflammation was about $11.9 \%$. After adjustment for age, gender, smoking habits and physical activity, higher BMI and fasting blood glucose values, and low adiponectin concentrations, were associated with a higher risk to develop inflammation.

\section{Effect of BMI on inflammation}

Obesity is a major cause of insulin resistance and associated metabolic dysregulation, including hypertension and dyslipidemia, which might trigger the development 
Table 2 Univariate analyses. Relationship between inflammation and related clinical and biological risk factors

\begin{tabular}{|c|c|c|c|c|}
\hline & \multicolumn{4}{|c|}{ Inflammation (hs-CRP $\geq 6 \mathrm{mg} / \mathrm{L}$ and IL- $6 \geq 2 \mathrm{pg} / \mathrm{mL}$ ) } \\
\hline & \multirow[t]{2}{*}{ OR } & \multicolumn{2}{|c|}{$95 \% \mathrm{Cl}$} & \multirow[t]{2}{*}{$P$ value } \\
\hline & & Min & Max & \\
\hline Age (Years) & 0.982 & 0.924 & 1.045 & 0.574 \\
\hline Gender (Men) & 0.971 & 0.304 & 3.104 & 0.961 \\
\hline Gender (Women) & 1.029 & 0.322 & 3.290 & 0.961 \\
\hline Smoking habits (Active) & 0.719 & 0.133 & 3.899 & 0.702 \\
\hline Smoking habits (Past) & 0.804 & 0.147 & 4.329 & 0.801 \\
\hline Smoking habits (Passive) & 1.079 & 0.243 & 4.782 & 0.920 \\
\hline Smoking habits (Never) & - & - & - & 0.971 \\
\hline Physical activity (Low) & 1.000 & 0.106 & 9.393 & 1.000 \\
\hline Physical activity (Moderate) & 0.875 & 0.088 & 8.660 & 0.909 \\
\hline Physical activity (High) & - & - & - & 0.976 \\
\hline BMI $\left(\mathbf{k g} / \mathrm{m}^{2}\right)$ & 1.154 & 1.039 & 1.282 & $0.008^{*}$ \\
\hline WC (cm) & 1.031 & 0.986 & 1.078 & 0.177 \\
\hline SBP (mmHg) & 1.011 & 0.977 & 1.047 & 0.524 \\
\hline $\mathrm{DBP}(\mathrm{mmHg})$ & 1.200 & 0.955 & 1.088 & 0.556 \\
\hline FBG (mg/dL) & 1.011 & 1.002 & 1.021 & $0.019 *$ \\
\hline $\mathrm{TC}(\mathrm{mg} / \mathrm{dL})$ & 0.966 & 0.979 & 1.013 & 0.623 \\
\hline TG (mg/dL) & 1.005 & 1.000 & 1.010 & $0.045^{*}$ \\
\hline Adiponectin (mg/L) & 0.761 & 0.615 & 0.942 & $0.012^{*}$ \\
\hline
\end{tabular}

Abbreviations: $B M I$ body mass index, WC waist circumference, SBP systolic blood pressure, DBP diastolic blood pressure, FBG fasting blood glucose, $T C$ total cholesterol, $T G$ triglyceride, $h s-C R P$ high sensitivity $C$ reactive protein, IL- 6 interleukin 6

${ }^{*} p$ values $\leq 0.05$ were considered as significant

of type 2 diabetes [36]. Metabolically unhealthy obesity is a major contributor to the development of T2DM and cardiovascular diseases, possibly due to the oxidative stress and inflammation increase [24, 37, 38]. Insulin resistance has significantly been associated with obesity. This is possibly due to the release of bioactive metabolites such as free fatty acids, monocyte chemoattractant protein-1 (MCP-1) and pro-inflammatory cytokines by the adipocytes [39]. Figure 1 describes the relationship between inflammatory markers and disease occurrence, from metabolically unhealthy overweight and obesity to T2DM and cardiovascular diseases [40, 41].

Table 3 Multivariable logistic predictive models of inflammation (hs-CRP $\geq 6 \mathrm{mg} / \mathrm{L}$ and IL-6 $\geq 2 \mathrm{pg} / \mathrm{mL}$ ) by clinical and biological risk factors

\begin{tabular}{|c|c|c|c|c|c|c|c|c|}
\hline & \multicolumn{4}{|c|}{ Model 1} & \multicolumn{4}{|c|}{ Model 2} \\
\hline & \multirow[t]{2}{*}{ OR } & \multicolumn{2}{|c|}{$95 \% \mathrm{Cl}$} & \multirow{2}{*}{$\begin{array}{l}P \\
\text { value }\end{array}$} & \multirow[t]{2}{*}{ OR } & \multicolumn{2}{|c|}{$95 \% \mathrm{Cl}$} & \multirow{2}{*}{$\begin{array}{l}P \\
\text { value }\end{array}$} \\
\hline & & Min & Max & & & Min & Max & \\
\hline BMI $\left(\mathrm{kg} / \mathrm{m}^{2}\right)$ & 1.427 & 1.055 & 1.931 & $0.021^{*}$ & 1.432 & 1.042 & 1.968 & $0.027^{*}$ \\
\hline WC $(\mathrm{cm})$ & 0.928 & 0.821 & 1.049 & 0.235 & 0.928 & 0.820 & 1.050 & 0.237 \\
\hline SBP $(\mathrm{mmHg})$ & 1.012 & 0.912 & 1.123 & 0.817 & 1.014 & 0.913 & 1.126 & 0.797 \\
\hline $\mathrm{DBP}(\mathrm{mmHg})$ & 0.942 & 0.780 & 1.139 & 0.538 & 0.938 & 0.771 & 1.141 & 0.520 \\
\hline FBG (mg/dL) & 1.029 & 1.007 & 1.052 & $0.010^{*}$ & 1.029 & 1.006 & 1.052 & $0.013^{*}$ \\
\hline TC (mg/dL) & 0.975 & 0.941 & 1.011 & 0.173 & 0.976 & 0.939 & 1.014 & 0.205 \\
\hline TG (mg/dL) & 1.006 & 0.998 & 1.014 & 0.153 & 1.006 & 0.998 & 1.015 & 0.166 \\
\hline Adiponectin (mg/L) & 0.571 & 0.361 & 0.903 & $0.017^{*}$ & 0.569 & 0.359 & 0.902 & $0.016^{*}$ \\
\hline
\end{tabular}

Model 1: adjusted for age, gender

Model 2: adjusted for age, gender, smoking habits, physical activity

Abbreviations: BMI body mass index, WC waist circumference, SBP systolic blood pressure, DBP diastolic blood pressure, FBG fasting blood glucose, TC total cholesterol, $T G$ triglyceride, $h s-C R P$ high sensitivity $C$ reactive protein, $I L-6$ interleukin 6

${ }^{*} p$ values $\leq 0.05$ were considered as significant 


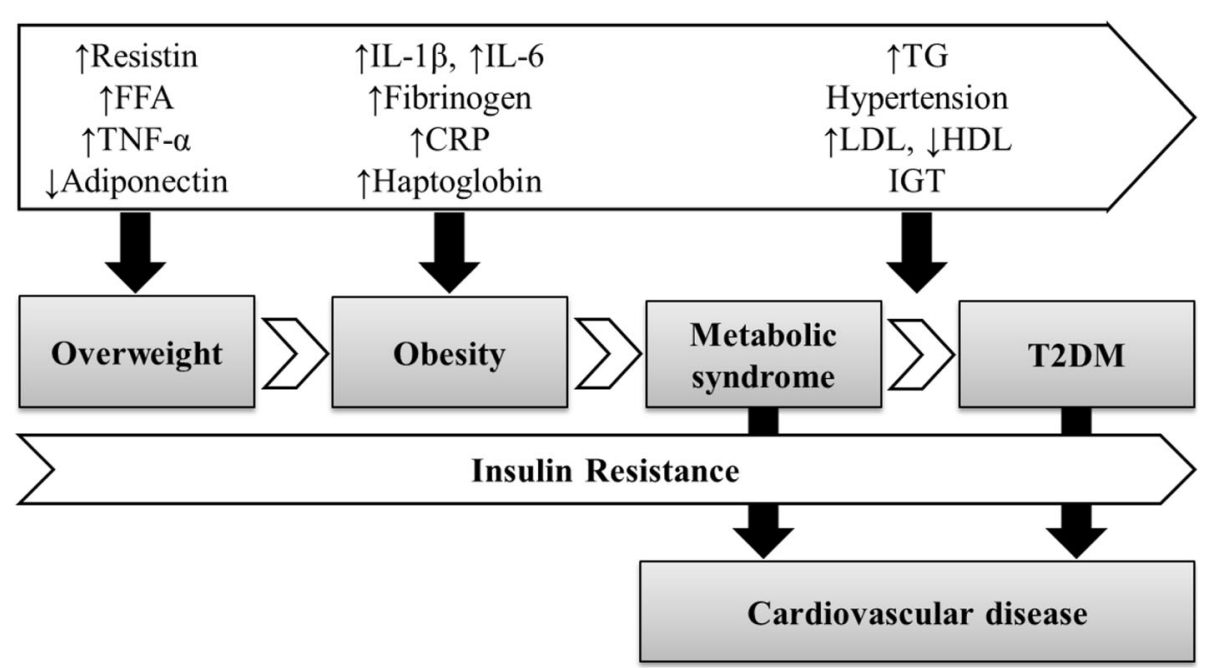

Fig. 1 Relationship between inflammation, metabolically unhealthy obesity and development of type 2 diabetes and cardiovascular diseases (Ellulu, 2017). Abbreviations: FFA: free fatty acids. IGT: impaired glucose tolerance. HDL: high-density lipoprotein. LDL: low-density lipoprotein. T2D: type 2 diabetes

Metabolically unhealthy obesity leads to the overexpression of CRP and IL-6, resulting in low-grade chronic inflammation [38]. A hyperplasia process might occur during the hypertrophy of the adipocytes as a response of the adipose tissue to over nutrition stimuli, inducing a permanent inflammatory state. Indeed, the enlarged adipocytes might reduce the blood supply to the fat cells and induce the hypoxia of the adipocytes [42]. This might consequently trigger the adipocytes necrosis as well as the infiltration of the macrophages in the adipose tissue, provoking the overproduction of pro-inflammatory mediators. This process induces the hyper-inflammation of the adipose tissue, which might results in a systemic inflammation and insulin-resistance, both possibly behind the development of obesity-related comorbidities [43]. In fact, the adipose tissue is not only a storage organ, but rather a metabolically dynamic organ, acting in interaction with the adipose, immune and endothelial cells functioning [44]. Three main inflammatory mediators are produced by the macrophages, the tumor necrosis factor-alpha (TNF$\alpha)$, the interleukin- 6 and the adiponectin [45]. The Creactive protein is released by the hepatocytes, these latter being stimulated by the IL- 6 , which trigger long grade chronic inflammation [46]. The IL-6 are in particular released by certain pro-inflammatory serine kinases such as the inhibitor of nuclear factor kappa $\mathrm{B}\left(\mathrm{I}_{\mathrm{k}} \mathrm{B}\right)$ and c-JunNterminal kinases, activated by the free fatty acids [47]. Several authors have investigated the significant relationship between obesity and inflammation. In particular, Straub et al. (2000) [48] highlighted that about one third of the total circulating IL- 6 are released from the adipose tissue [49]. In fact, increased evidence has displayed that obesity constitutes a low-grade inflammatory state, possibly associated with metabolic dysregulation [50].

For instance, Dayal et al. (2014) [51] found that with each one unit of increment in BMI, CRP was more likely to increase by $37 \%(95 \%$ CI: $1.23-1.53, \quad P<0.001)$ amongst Indian children. Likewise, Klisic et al. (2014) [52] found that the level of CRP amongst postmenopausal women having obesity in Montenegro was higher than in post-menopausal women with normal weight $(P<0.001)$. Similarly, Kawamoto et al. (2013) [53] observed that BMI was the most significant predictor of inflammation, as assessed by CRP in communitydwelling persons. This was confirmed by several authors and in several populations. In particular, Warnberg et al. (2004) [54] showed high levels of CRP amongst Spanish adolescents having obesity, compared to the adolescents with normal weight as assessed by BMI $(P<0.05)$. Similar findings were observed regarding the relationship between BMI and IL-6 expression. In particular, Wannamethee et al. (2007) [55] showed increased IL-6 concentrations in 60-79 years old British men having obesity. Similarly, Rexrode et al. (2003) [56] confirmed the positive correlation between BMI and IL- 6 amongst women who were free from cardiovascular diseases.

Likewise, Pradhan et al. (2001) [21] evaluated the level of inflammatory markers among US women having diabetes, compared to US women free of diabetes, through a prospective case-control study. The average BMI in women having diabetes was significantly higher $(31.8 \mathrm{~kg} /$ $\mathrm{m}^{2}$ ) than in women free of diabetes $\left(25.6 \mathrm{~kg} / \mathrm{m}^{2}\right)$. Similarly, the median of IL-6 in women having diabetes was about $2.0 \mathrm{pg} / \mathrm{mL}$, compared to women free of diabetes 
$(1.38 \mathrm{pg} / \mathrm{mL})$. As well, the median of CRP in women having diabetes was significantly higher $(0.69 \mathrm{mg} / \mathrm{dL})$ than in women free of diabetes $(0.26 \mathrm{mg} / \mathrm{dL})$.

\section{Effect of adiponectin on inflammation}

Low adiponectin levels have been highlighted as having a significant impact on obesity occurrence, type 2 diabetes development and cardiovascular diseases raise, probably due to the adiponectin related insulin resistance and inflammation $[57,58]$. Weight gain and obesity have in particular been associated with low serum levels of adiponectin [59]. Especially, the role played by the visceral adipocytes in releasing adiponectin has been emphasized [60]. Actually, increased serum level of inflammatory mediators such as IL- 6 and TNF- $\alpha$, released by the adipocytes, seem to inhibit the synthesis and secretion of adiponectin [60]. Conversely, in individuals with a metabolically healthy profile, adiponectin was associated with low inflammation levels, as well as a reduced risk of T2DM and atherosclerosis [60]. The role of high adiponectin levels in improving insulin resistance and immune system by its anti-inflammatory effect is described in Fig. 2, adapted from Ellulu et al. (2017) [40, 41]. The relationship between adiponectin and inflammatory markers has been highlighted in several studies. In particular, the hypoadiponectinemia status was previously significantly correlated with increased inflammation, as asessed by IL-6 [26]. Likewise, Hung et al. (2008) [61] highlighted a significant opposite relationship between adiponectin and inflammation as assessed by IL- 6 and CRP, after adjustment for age, gender, waist to hip ratio and smoking habits.

\section{Effect of high fasting blood glucose levels on inflammation}

Insulin resistance and $\beta$-cell exhaustion provoke an impaired glucose tolerance state, inducing the development of type 2 diabetes [62]. As shown in Fig. 1, inflammation triggers the insulin resistance, which might lead to T2DM raise [63]. Also, the relationship between inflammation and insulin resistance has been shown to be mediated by obesity [39]. Actually, inflammatory markers have been shown to be higher amongst individuals having high fasting blood glucose levels and metabolically unhealthy obesity [64]. Thus, the relationship between FBG and inflammatory markers in the present study is in accordance with the previously published studies. Lee et al. (2011) [65] showed a concomitant increase of CRP and FBG concentrations $(P=0.002)$, leading to cardiovascular events. Kawamoto et al. (2011) [64] observed significantly high CRP values related to fasting glucose in Japanese individuals displaying high levels of FBG $(\geq 100 \mathrm{mg} / \mathrm{dL}) \quad(P=0.033)$, compared to Japanese

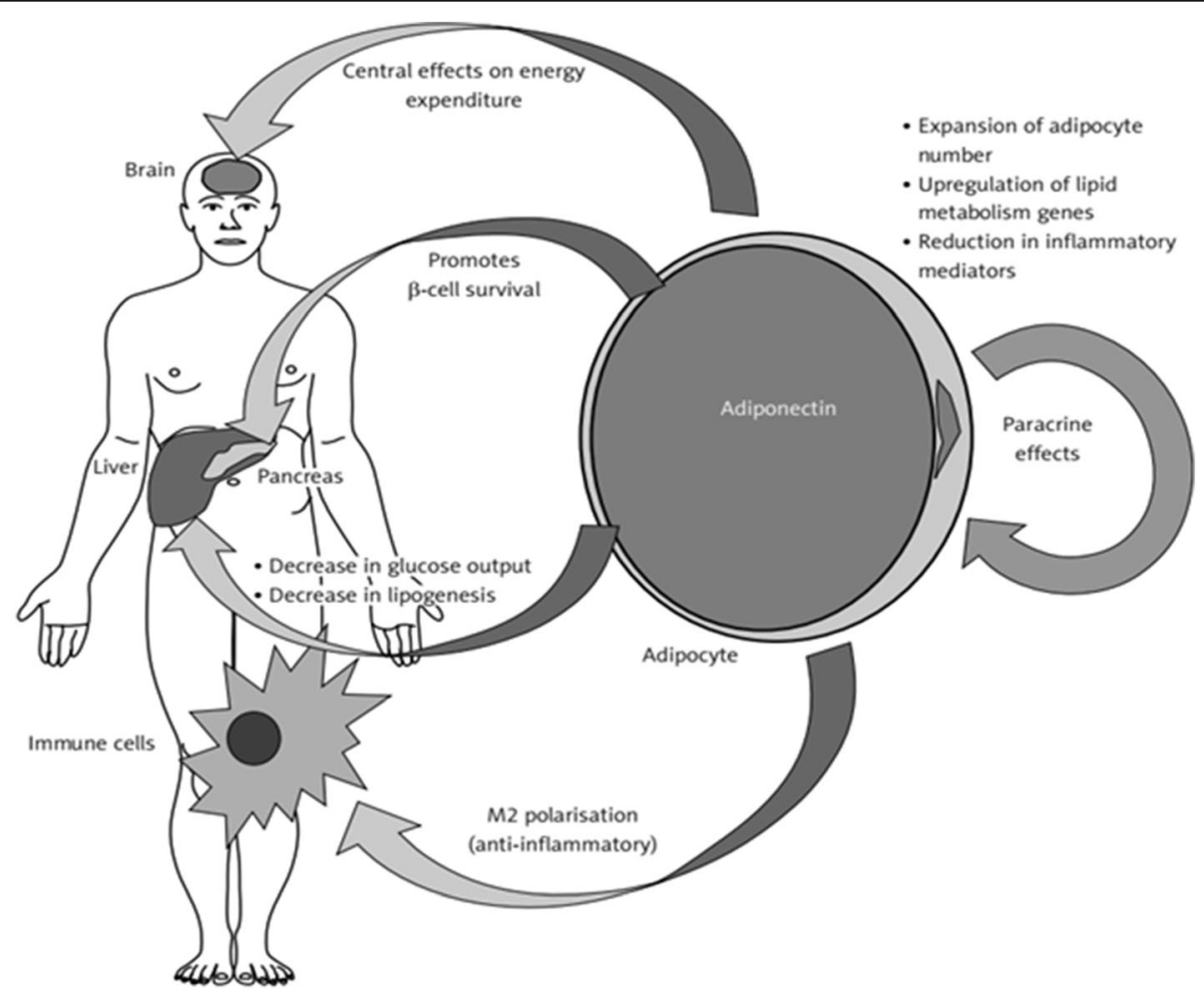

Fig. 2 The role of Adiponectin on peripheral tissues insulin sensitivity (Ellulu et al., 2017) 
individuals displaying low levels of FBG $(<100 \mathrm{mg} / \mathrm{dL})$. This was also true amongst urban Portuguese adults, as well as in an adult population-based study in Germany, where CRP levels were significantly higher in individuals having elevated FBG levels, and were associated with metabolic syndrome occurrence [66, 67].

Similarly, Sarvottam and Yadav (2014) [26] identified that increased fasting blood glucose levels were significantly and positively correlated with inflammation as assessed by IL- 6 concentrations, as well as with an increased endothelial dysfunction. Finally, Dandona et al. (2004) [68] highlighted that a high macronutrient intake, associated with obesity, was also significantly correlated with oxidative stress and inflammatory mediators (IL-6, TNF- $\alpha$ ) increase.

\section{Limitation}

A possible limitation of the present study might be due to its cross-sectional design. Therefore, we cannot conclude on any causality relationship in the interpretation of our findings.

\section{Conclusion}

The present study highlighted increased BMI, high fasting blood glucose levels, as well as decreased adiponectin concentrations as clinical and biological risk factors of inflammation in a sample of patients with T2DM. Inflammation was defined for IL- $6 \geq 2 \mathrm{pg} / \mathrm{mL}$ and CRP $\geq$ $6 \mathrm{mg} / \mathrm{L}$.

Tackling obesity and associated complications (i.e. hyperglycemia, high adiponectin levels) might help to decrease inflammation in individuals with T2DM.

\section{Recommendations for future research}

We do recommend the measurement of body mass index and fasting blood glucose as risk factors of inflammation in patients with type 2 diabetes. Adiponectin might be difficult to measure in clinical routine. Glycosylated Hemoglobin (HbA1c) assessment should be considered, as a more sensitive biochemical marker than fasting blood glucose for type 2 diabetes diagnosis, when an appropriate funding is available to measure it.

\section{Abbreviations}

BMI: Body mass index; BP: Blood pressure; BRFSS: The Behavioral Risk Factor Surveillance System; COX-2: Cyclooxygenase-2; CRP: C-reactive protein; DBP: Diastolic blood pressure; FBG: Fasting blood glucose; GPAQ: Global Physical Activity Questionnaire; HbA1c: Glycosylated Hemoglobin; HDLcholesterol: High-density lipoprotein cholesterol; IDF: International Diabetes Federation; I B: Inhibitor of nuclear factor kappa B; IL-6: Interleukin 6; MCP1: Monocyte chemoattractant protein-1; NCEP-ATPIII: National Cholesterol Education Program-Adult Treatment Panel III; NIH: National Institute of Health; NSAIDs: Nonsteroidal anti-inflammatory drugs; OR: Odd-ratio; SBP: Systolic blood pressure; SD: Standard deviation; SPSS: Statistical Package for Social Sciences; TC: Total cholesterol; TG: Triglycerides; TNF-a: Tumor necrosis factor-alpha; T2DM: Type 2 diabetes mellitus; WHO: World Health Organization; WC: Waist circumference

\section{Supplementary Information}

The online version contains supplementary material available at https://doi. org/10.1186/s12902-021-00925-0.

Additional file 1. Case Report Form. Case Report Form including the questionnaire on socio-demographics factors, medical history, smoking habits, physical activity pattern, physical examination and biochemical measures.

\section{Acknowledgments}

The Authors thank the participants to have taken part to the study. We thank the Palestinian Ministry of Health to have provided us with the agreement to conduct the study fieldwork. We also thank the Faculty of Medicine and Health Sciences at University Putra Malaysia to have made available its library.

\section{Authors' contributions}

MSE designed the study, collected the data, performed the statistics and wrote the first draft of the manuscript. HS took actively part to the manuscript writing and advised on the statistical analyses. Both authors critically revised the manuscript for important intellectual content and approved the version to be published.

Funding

"Not Applicable".

Availability of data and materials

The datasets used and/or analyzed during the current study are available upon request. The data requests should be addressed to Mohammed S. Ellulu.

\section{Declarations}

\section{Ethics approval and consent to participate}

All procedures performed in studies involving human subjects were in accordance with the ethical standards of the institutional and/or national research committee and with the 1964 Helsinki Declaration and its later amendments or comparable ethical standards. This study was approved by Universiti Putra Malaysia (reference no. [FPSK_Mac (13)04]) and ethically approved by the Helsinki Committee for Ethical Approval of Gaza, Palestine (no. [PHRC/HC/11/13]). The study participants gave their written informed consent prior to taking part in the study.

Consent for publication

Not applicable.

\section{Competing interests}

The authors declare having no conflict of interest.

\section{Author details}

${ }^{1}$ Department of Clinical Nutrition, Faculty of Applied Medical Sciences, Al-Azhar University - Gaza (AUG), Gaza, Palestine. ${ }^{2}$ Luxembourg Institute of Health, Population Health Department, L-1445 Strassen, Luxembourg.

Received: 9 March 2021 Accepted: 22 December 2021

Published online: 06 January 2022

References

1. American Diabetes A. (2) classification and diagnosis of diabetes. Diabetes Care. 2015;38(Suppl):S8-S16.

2. International Diabetes Federation. IDF clinical practice recommendations for managing type 2 diabetes in primary care. 2017. https://www.idf.org/e-libra ry/guidelines/128-idf-clinical-practice-recommendations-for-managingtype-2-diabetes-in-primary-care.html.

3. Centers for Disease Control and Prevention (CDC). National diabetes statistics report, estimates of diabetes and its burden in the United States. 2020.

4. Ceriello A. Oxidative stress and diabetes-associated complications. Endocr Pract. 2006;12(Suppl 1):60-2. 
5. Lozano R, Naghavi M, Foreman K, Lim S, Shibuya K, Aboyans V, et al. Global and regional mortality from 235 causes of death for 20 age groups in 1990 and 2010: a systematic analysis for the global burden of disease study 2010. Lancet. 2012;380(9859):2095-128.

6. International Diabetes Federation, 2019. IDF Diabetes Atlas 9th edition [https://diabetesatlas.org/atlas/ninthedition/].

7. Wang Y, Mi J, Shan XY, Wang QJ, Ge KY. Is China facing an obesity epidemic and the consequences? The trends in obesity and chronic disease in China. Int J Obes. 2007:31(1):177-88.

8. Amuna P, Zotor FB. Epidemiological and nutrition transition in developing countries: impact on human health and development. Proc Nutr Soc. 2008; 67(1):82-90.

9. Schwab U, Lauritzen L, Tholstrup T, Haldorssoni T, Riserus U, Uusitupa M et al. Effect of the amount and type of dietary fat on cardiometabolic risk factors and risk of developing type 2 diabetes, cardiovascular diseases, and cancer: a systematic review. Food Nutr Res. 2014;58:25145. http://dx.doi. org/10.3402/fnr.v58.25145.

10. Paprott R, Mensink GBM, Schulze MB, Thiele S, Muhlenbruch $K$, Scheidt-Nave

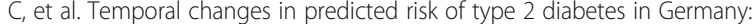
findings from the German health interview and examination surveys 19971999 and 2008-2011. BMJ Open. 2017;7(7):e013058.

11. Ng SW, Zaghloul S, Ali HI, Harrison G, Popkin BM. The prevalence and trends of overweight, obesity and nutrition-related non-communicable diseases in the Arabian Gulf States. Obes Rev. 2011;12(1):1-13.

12. Ali O. Genetics of type 2 diabetes. World J Diabetes. 2013;4(4):114-23.

13. Franks PW. Gene $x$ environment interactions in type 2 diabetes. Curr Diab Rep. 2011;11(6):552-61

14. Abukhdeir HF, Caplan LS, Reese L, Alema-Mensah E. Factors affecting the prevalence of chronic diseases in Palestinian people: an analysis of data from the Palestinian central Bureau of Statistics. East Mediterr Health J. 2013; 19(4):307-13.

15. Liu W, Hua L, Liu WF, Song HL, Dai XW, Yang JK. The prevalence of glucose metabolism disturbances in Chinese Muslims and possible risk factors: a study from northwest China. Arq Bras Endocrinol Metabol. 2014;58(7):715723.

16. Hsu WC, Araneta MR, Kanaya AM, Chiang JL, Fujimoto W. BMI cut points to identify at-risk Asian Americans for type 2 diabetes screening. Diabetes Care. 2015:38(1):150-8.

17. American Diabetes A. Diagnosis and classification of diabetes mellitus. Diabetes Care. 2010;33(Suppl 1):S62-9.

18. Tsalamandris S, Antonopoulos AS, Oikonomou E, Papamikroulis GA, Vogiatzi G, Papaioannou S, et al. The role of inflammation in diabetes: current concepts and future perspectives. Eur Cardiol. 2019;14(1):50-9.

19. Marques-Vidal P, Schmid R, Bochud M, Bastardot F, von Kanel R, Paccaud F, et al. Adipocytokines, hepatic and inflammatory biomarkers and incidence of type 2 diabetes. The CoLaus study. PLoS One. 2012;7(12):e51768.

20. Sakashita Y, Nakanishi S, Yoneda M, Nakashima R, Yamane K, Kohno N Regardless of central obesity, metabolic syndrome is a significant predictor of type 2 diabetes in Japanese Americans. J Diabetes Investig. 2015;6(5): 527-32

21. Pradhan AD, Manson JE, Rifai N, Buring JE, Ridker PM. C-reactive protein interleukin 6, and risk of developing type 2 diabetes mellitus. JAMA. 2001; 286(3):327-34

22. Löbner K, Füchtenbusch M. Inflammation and diabetes. MMW Fortschr Med. 2004:146(35-36):32-33, 35-36.

23. Adar SD, D'Souza J, Mendelsohn-Victor K, Jacobs DR, Cushman M, Sheppard $L$, et al. Markers of inflammation and coagulation after long-term exposure to coarse particulate matter: a cross-sectional analysis from the multi-ethnic study of atherosclerosis. Environ Health Perspect. 2015;123(6):541-8.

24. Chen SJ, Yen CH, Huang YC, Lee BJ, Hsia S, Lin PT. Relationships between inflammation, adiponectin, and oxidative stress in metabolic syndrome. PLoS One. 2012;7(9):e45693.

25. Ellulu MS, Patimah I, Khaza'ai H, Rahmat A, Abed Y, Ali F. Atherosclerotic cardiovascular disease: a review of initiators and protective factors. Inflammopharmacology. 2016;24(1):1-10.

26. Sarvottam K, Yadav RK. Adiponectin, interleukin-6, and endothelin-1 correlate with modifiable cardiometabolic risk factors in overweight/obese men. J Altern Complement Med. 2014;20(5):419-20.

27. Cirillo P, Sautin YY, Kanellis J, Kang DH, Gesualdo L, Nakagawa T, et al. Systemic inflammation, metabolic syndrome and progressive renal disease. Nephrol Dial Transplant. 2009;24(5):1384-7.
28. Zhou B, Liu J, Wang ZM, Xi T. C-reactive protein, interleukin 6 and lung cancer risk: a meta-analysis. PLoS One. 2012;7(8):e43075.

29. WHO. Obesity: preventing and managing the global epidemic. Report of a WHO Consultation, WHO Technical Report Series 894; 2000. p. 252.

30. Lorenzo C, Williams K, Hunt K, Haffner SM. The national cholesterol education program - adult treatment panel III, international Diabetes federation, and World Health Organization definitions of the metabolic syndrome as predictors of incident cardiovascular disease and diabetes. Diabetes Care. 2007;30(1):8-13.

31. Weber MA, Schiffrin EL, White WB, Mann S, Lindholm LH, Kenerson JG, et al. Clinical practice guidelines for the management of hypertension in the community: a statement by the American Society of Hypertension and the International Society of Hypertension. J Clin Hypertens (Greenwich). 2014; 16(1):14-26

32. Expert Panel on Detection E, Treatment of High Blood Cholesterol in A. Executive summary of the third report of the National Cholesterol Education Program (NCEP) expert panel on detection, evaluation, and treatment of high blood cholesterol in adults (adult treatment panel III). JAMA. 2001:285(19):2486-97.

33. Pearson TA, Mensah GA, Alexander RW, Anderson JL, Cannon RO 3rd, Criqui $M$, et al. Markers of inflammation and cardiovascular disease: application to clinical and public health practice: a statement for healthcare professionals from the Centers for Disease Control and Prevention and the American Heart Association. Circulation. 2003;107(3):499-511.

34. World Health Organization Department of Non-communicable Diseases. Global physical activity questionnaire and analysis guide. 2002

35. Centers for Disease Control and Prevention (CDC). Behavioral risk factor surveillance system survey questionnaire. Atlanta: US Department of Health and Human Services, Centers for Disease Control and Prevention; 2011.

36. Badawi A, Klip A, Haddad P, Cole DE, Bailo BG, El-Sohemy A, et al. Type 2 diabetes mellitus and inflammation: prospects for biomarkers of risk and nutritional intervention. Diabetes Metab Syndr Obes. 2010;3:173-86.

37. Pajunen P, Kotronen A, Korpi-Hyovalti E, Keinanen-Kiukaanniemi S, Oksa H, Niskanen L, et al. Metabolically healthy and unhealthy obesity phenotypes in the general population: the FIN-D2D survey. BMC Public Health. 2011;11:754.

38. Hotamisligil GS. Inflammation and metabolic disorders. Nature. 2006; 444(7121):860-7.

39. Shoelson SE, Lee J, Goldfine AB. Inflammation and insulin resistance. J Clin Invest. 2006;116(7):1793-801.

40. Ellulu MS. Obesity, cardiovascular disease, and role of vitamin C on inflammation: a review of facts and underlying mechanisms. Inflammopharmacology. 2017;25(3):313-28.

41. Ellulu MS, Patimah I, Khaza'ai H, Rahmat A, Abed Y. Obesity and inflammation: the linking mechanism and the complications. Arch Med Sci. 2017:13(4):851-63.

42. Cinti S, Mitchell G, Barbatelli G, Murano I, Ceresi E, Faloia E, et al. Adipocyte death defines macrophage localization and function in adipose tissue of obese mice and humans. J Lipid Res. 2005;46(11):2347-55.

43. Trayhurn P, Wood IS. Adipokines: inflammation and the pleiotropic role of white adipose tissue. Br J Nutr. 2004;92(3):347-55.

44. Halberg N, Wernstedt-Asterholm I, Scherer PE. The adipocyte as an endocrine cell. Endocrinol Metab Clin N Am. 2008;37(3):753-768, x-xi.

45. Karastergiou K, Mohamed-Ali $\mathrm{V}$. The autocrine and paracrine roles of adipokines. Mol Cell Endocrinol. 2010;318(1-2):69-78.

46. Zhang S, Liu Q, Wang J, Harnish DC. Suppression of interleukin-6-induced Creactive protein expression by FXR agonists. Biochem Biophys Res Commun. 2009;379(2):476-9.

47. Rocha VZ, Libby P. Obesity, inflammation, and atherosclerosis. Nat Rev Cardiol. 2009;6(6):399-409.

48. Straub RH, Hense HW, Andus T, Scholmerich J, Riegger GA, Schunkert H. Hormone replacement therapy and interrelation between serum interleukin- 6 and body mass index in postmenopausal women: a population-based study. J Clin Endocrinol Metab. 2000;85(3):1340-4

49. Fontana L, Eagon JC, Trujillo ME, Scherer PE, Klein S. Visceral fat adipokine secretion is associated with systemic inflammation in obese humans. Diabetes. 2007:56(4):1010-3.

50. Scheller J, Chalaris A, Schmidt-Arras D, Rose-John S. The pro- and antiinflammatory properties of the cytokine interleukin-6. Biochim Biophys Acta. 2011;1813(5):878-88.

51. Dayal D, Jain H, Attri SV, Bharti B, Bhalla AK. Relationship of high sensitivity C-reactive protein levels to anthropometric and other metabolic parameters 
in Indian children with simple overweight and obesity. J Clin Diagn Res. 2014:8(8):PC05-8.

52. Klisic AN, Vasiljevic ND, Simic TP, Djukic TI, Maksimovic MZ, Matic MG. Association between C-reactive protein, anthropometric and lipid parameters among healthy normal weight and overweight postmenopausal women in Montenegro. Lab Med. 2014;45(1):12-6.

53. Kawamoto R, Kusunoki T, Abe M, Kohara K, Miki T. An association between body mass index and high-sensitivity $\mathrm{C}$-reactive protein concentrations is influenced by age in community-dwelling persons. Ann Clin Biochem. 2013; 50(Pt 5):457-64.

54. Warnberg J, Moreno LA, Mesana MI, Marcos A, group A. Inflammatory mediators in overweight and obese Spanish adolescents. The AVENA study. Int J Obes Relat Metab Disord. 2004;28(Suppl 3):S59-63.

55. Wannamethee SG, Whincup PH, Rumley A, Lowe GD. Inter-relationships of interleukin-6, cardiovascular risk factors and the metabolic syndrome among older men. J Thromb Haemost. 2007;5(8):1637-43.

56. Rexrode KM, Pradhan A, Manson JE, Buring JE, Ridker PM. Relationship of total and abdominal adiposity with CRP and IL-6 in women. Ann Epidemiol. 2003;13(10):674-82.

57. Matsuda M, Shimomura I, Sata M, Arita Y, Nishida M, Maeda N, et al. Role of adiponectin in preventing vascular stenosis. The missing link of adipovascular axis. J Biol Chem. 2002;277(40):37487-91.

58. Bastard JP, Maachi M, Lagathu C, Kim MJ, Caron M, Vidal H, et al. Recent advances in the relationship between obesity, inflammation, and insulin resistance. Eur Cytokine Netw. 2006;17(1):4-12.

59. Ricci $R$, Bevilacqua F. The potential role of leptin and adiponectin in obesity: a comparative review. Vet J. 2012;191(3):292-8.

60. Matsuzawa Y. The metabolic syndrome and adipocytokines. FEBS Lett. 2006; 580(12):2917-21.

61. Hung J, McQuillan BM, Thompson PL, Beilby JP. Circulating adiponectin levels associate with inflammatory markers, insulin resistance and metabolic syndrome independent of obesity. Int J Obes. 2008;32(5):772-9.

62. Stumvoll M, Goldstein BJ, van Haeften TW. Type 2 diabetes: principles of pathogenesis and therapy. Lancet. 2005;365(9467):1333-46.

63. King GL. The role of inflammatory cytokines in diabetes and its complications. J Periodontol. 2008;79(8 Suppl):1527-34.

64. Kawamoto R, Tabara Y, Kohara K, Miki T, Kusunoki T, Takayama S, et al. Association between fasting plasma glucose and high-sensitivity C-reactive protein: gender differences in a Japanese community-dwelling population. Cardiovasc Diabetol. 2011;10:51.

65. Lee S, Kim IT, Park HB, Hyun YK, Kim YJ, Song SO, et al. High-sensitivity Creactive protein can predict major adverse cardiovascular events in Korean patients with type 2 diabetes. J Korean Med Sci. 2011;26(10):1322-7.

66. Santos AC, Lopes C, Guimaraes JT, Barros H. Central obesity as a major determinant of increased high-sensitivity C-reactive protein in metabolic syndrome. Int J Obes. 2005;29(12):1452-6.

67. Frohlich M, Imhof A, Berg G, Hutchinson WL, Pepys MB, Boeing H, et al. Association between C-reactive protein and features of the metabolic syndrome: a population-based study. Diabetes Care. 2000;23(12):1835-9.

68. Dandona P, Aljada A, Bandyopadhyay A. Inflammation: the link between insulin resistance, obesity and diabetes. Trends Immunol. 2004;25(1):4-7.

\section{Publisher's Note}

Springer Nature remains neutral with regard to jurisdictional claims in published maps and institutional affiliations.

\section{Ready to submit your research? Choose BMC and benefit from}

- fast, convenient online submission

- thorough peer review by experienced researchers in your field

- rapid publication on acceptance

- support for research data, including large and complex data types

- gold Open Access which fosters wider collaboration and increased citations

- maximum visibility for your research: over $100 \mathrm{M}$ website views per year

At BMC, research is always in progress.

Learn more biomedcentral.com/submissions 